Journal of Primary Education
$9(5)(2020): 472-481$

\title{
Students' Concepts Understanding Through Inquiry Learning Model Based on Local Wisdom in the Theme of "Heat and Its Transfer"
}

\author{
Silva Nadhifatul A'yun ${ }^{1 凶}$, Siti Alimah ${ }^{2}$, Ngurah Made Dharma Putra ${ }^{2}$ \\ DOI: https://doi.org/ 10.15294/jpe.v9i5.42966 \\ 1. PGSD, FKIP Universitas Islam Sultan Agung Semarang \\ 2. Pascasarjana, Universitas Negeri Semarang, Indonesia
}

\begin{tabular}{l} 
Article Info \\
\hline History Articles \\
Received: \\
14 August 2020 \\
Accepted: \\
20 September 2020 \\
Published: \\
31 December 2020 \\
\hline Keywords: \\
inquiry model, \\
conceptual \\
understanding, local \\
wisdom
\end{tabular}

\begin{abstract}
This study aims to analyze the improvement and profile of students' conceptual understanding through a local wisdom-based inquiry model. This research used mixed method with a sequential explanatory design. The population in this study were all class 5 students from six elementary schools in Mayong Jepara. The selection of sample of this study used simple random sampling technique. The study has two sample of class 5 of SD Negeri 2 and SD Negeri 3 Mayong Lor with 27 student and 30 student as the sample, respectively. The first stage is a quantitative method in the form of a true-experimental design with a pre-test and post-test control group design type. Data collection was used test, to know the understanding of the student on heat transfer concept. Then completed using documentation and interview for qualitative stage. Then for data analysis was used n-gain test and description according to Miles and Hubermans models. Based on the conceptual understanding score shows the average score obtained by the experimental class student was increased from 51.48 to 77.41 and the control class obtained an average increase from 52.33 to 66.00. The results of the average difference test of students' conceptual understanding show that the sig. (2-tailed) value generated is $0.001<0.05$, it indicates $\mathrm{H}_{0}$ is rejected, which means that there is a difference in conceptual understanding between the inquiry class and the local wisdom-based inquiry class. The profile of concept understanding on each indicator of class 5 students on the theme of heat and its transfer through the inquiry model as a whole is included in the good category with a percentage of 79.32 and the results of the interviews showed that students are easier to understand the material conveyed through direct observation to the roof tile manufacturing company.
\end{abstract}

\footnotetext{
Correspondence address:

Gedung A Kampus Pascasarjana UUNES, J1. Kelud Utara III

Semarang 50237, Indonesia

E-mail: silvaayun194@gmail.com
} 


\section{INTRODUCTION}

Science subject is one of the compulsory subjects included in elementary school curriculum. Science is a process of discovery and a way of finding out about nature systematically, not just mastery of knowledge in the form of facts, concepts or principles (Kemendikbud, 2013). The science learning process in elementary schools requires teachers to be as creative as possible so that they can deliver material in detail in accordance with the concept of science learning which is not only through lectures but also must involve active student participation.

For that purposes, The teacher in the learning process associates the phenomena that occur in everyday life with the concepts being studied. That means, student will have ability to corelate the subject matter to experiences in the context of their daily life. Rahmani, et al. (2016) stated that learning will be more meaningful if students find concepts that are learned by themselves through the observation process.

In fact, currently, learning has only focused on delivering material from textbooks. Atmojo (2012) says that learning recently tends to only prioritize the development of the intellectual aspects of students by making books as the main learning resource. Based on the results of observations and interviews with class 5 teacher of SD Negeri 2 Mayong Lor, it was stated that the science learning material includes of heat transfer process, the process of changing the form of an object, water cycles and dominant substances is delivered by using lectures and assignments methods. Active student involvement in learning tends to be low because learning is only teacher-centered and students are not given the opportunity to ask questions, so students are less motivated in learning. Another fact is that teacher rarely invites students to carry out experimental activities, for example in learning material of the process of changing the form of an object, teacher does not guide students in making experimental designs so that students tend to get difficulties in understanding the material.
The results of the final examination scores for the Science subjects in the academic year 2018/2019 showed unsatisfactory results with many students who did not reach the Minimum Completeness Criteria or Kriteria Ketuntasan Minimum (KKM). This condition reflects that students have lack of understanding in term of the heat transfer material presented by the teacher, as we have known based on the reality in the field. Cognitive abilities that are trained in the learning process include $\mathrm{C} 1, \mathrm{C} 2$ and $\mathrm{C} 3$. In other words, the highest level of students' cognitive abilities is C3, which means "apply". In the end of the learning process, students are expected to able to answer questions that have been studied. However, there is no learning process that trains students' analytical skills (C4). Student activities tend to be passive because students only act as recipients. The learning process does not provide opportunities for students to find their own concepts or idea.

Passive student activity proves that the level of student understanding of the concept of learning material is still low. Good science learning should use skills in learning activities, so that students can understand the concept from their experiences. In order to make students that are not only fixated on textbooks and are able to understand concepts in science, there is a need for innovation in learning, one of which is by using an inquiry model. According to Winnie (2014), guided inquiry activities focus on the core concepts and processes so as to encourage and foster a deep understanding of the material through observing, collecting data, analyzing data, synthesizing data until the conclusions are drawn. The stages in guided inquiry will make students more active in learning because students not only read and listen, but also think and act to find knowledge.

One alternative to the discovery of student knowledge which then becomes a student concept is by linking science knowledge with everyday life in learning process. The use of local wisdom as teaching materials, media and learning resources will provide more optimal results when combined with an appropriate learning model (Wanabuliandari et al, 2018). 
Elementary school students are still in the development of a concrete operational stage where students still need concrete objects to understand a material, so this study integrated the inquiry learning model with local wisdom. This similar to Dewi et al. (2017), that to help students better understand science concepts and develop process skills, local culture or wisdom that develops in a community or in a certain area can be used. Jepara is one of the districts in Central Java that has a lot of local potential (Nafisah, \& Ansori, 2019), including the roof tile-making industry in Mayong sub-district, the monel industry in Kalinyamat sub-district, the brick-making industry in Welahan sub-district, the Troso weaving industry in Pecangaan subdistrict and the carving industry which is almost spread out throughout the district. However, it is given that we are in an era of globalization, that young people no longer recognize the culture in the area where they live, so including local wisdom in the subject matter is important to do.

The large number of local potentials in Jepara can be utilized and integrated in the science learning process in school. For example most of the livelihood is making roof tiles, so students will find out that in the process of making roof tiles. During making process of roof tile can explain using science concept, such as on heat subject and how the heat can be transferred out that it uses science principles, especially the theme of hot and its transfer. That mean, the process of making roof tile can be used on the learning resources during learning process. Science learning based on local wisdom leads students to observe or make direct and indepth observations in the environment where they live (Khusniati, 2014). Alimah (2019) also states that local wisdom has the potential to be an innovative learning source so that students will be easy to understand learning material.

The inquiry model based on local wisdom is an alternative to overcome the problem of students' low conceptual understanding. Similar research conducted by Hariyadi et al., 2016; Pramadi et al., 2013; Lathifah \& Wilujeng, 2016; Simsek \& Kabapinar, 2010. Students' understanding of the concepts taught by environment-based inquiry shows that the concepts obtained are stronger in students' memories. Learning activities using an inquiry model based on local wisdom are not only in the form of transfer of knowledge from teachers to students, but students are also conditioned to be actively involved in learning activities. Science learning has been focused on activities carried out by applying certain material concepts with the inquiry model, so that students' low mastery of concepts can be improved (Anam et al., 2019).

Based on previous studies, researcher saw that the study was carried out by using only inquiry variables, only local wisdom or conceptual understanding and the most fundamental differences were the indicators of each variable. The research method also has differences with previous research, namely using experimental design research. So that, this study was really different to previous ones.

The research questions of this study include; a) Can the inquiry model based on local wisdom improve students' conceptual understanding? b) How is the difference in concept understanding among classes with different treatments? and c) What is the profile of conceptual understanding before and after treatment by using a local wisdom-based inquiry model?

Finally, this study aims to analyze the improvement and profile of students' conceptual understanding through a local wisdom-based inquiry model.

\section{METHOD}

The research method used by this study was Mixed Methods with a sequential explanatory design. The first stage of research used quantitative methods and in the second stage was qualitative methods. The procedure for this research is as follows:

1. Selecting the class as the sample in the school where the local wisdom-based inquiry model is implemented.

2. Prepare learning tools.

3. Doing test questions in other classes using the tests that have been made. 
4. Conducting discussions and debriefing teachers related to the implementation of inquiry model based on local wisdom

5. Giving a pre-test using a concept understanding test which aims to determine the students' initial abilities.

6. Applying the local wisdom-based inquiry learning model for the experimental class and the inquiry model for the control class.

7. Providing post-test after learning.

8. Analyzing data from the post-test results.

9. Conducting interviews with several students with high, medium and low category understanding of the concept of students to reveal more about the profiles of students' understanding in the concept of heat and its transfer.

10. Developing research results and drawing conclusions.

The samples in this study were 27 students of class 5 in SD Negeri 2 Mayonglor and SD Negeri 3 Mayonglor with a total of 30 students. The first stage is a quantitative method in the form of a true-experimental design with a pre-test post-test control group design type. The instrument used was in the form of a test for understanding the concept of heat and its transfer which consisted of 10 questions that contained aspects of concept understanding, such as exemplifying, classifying, summarizing and attracting inferences. The second stage is a qualitative method to get depth information for support quantitative data. The tsample technique was used purposive sampling, which is have three subject type was obtained. The instruments were used documentation and interview sheet.

The independent variable in this study is an inquiry model based on local wisdom which can be seen from student learning in class 5 on the theme of heat and its transfer. The dependent variable in this study is students' understanding of the concept. The research design is shown in Table 1.

Table 1. True-Experimental design

\begin{tabular}{llll}
\hline Group & Pre-test & Treatment & Post-test \\
\hline $\mathrm{E}$ & $\mathrm{O}_{1}$ & $\mathrm{X}$ & $\mathrm{O}_{2}$ \\
$\mathrm{~K}$ & $\mathrm{O}_{3}$ & $\mathrm{Y}$ & $\mathrm{O}_{4}$ \\
\hline
\end{tabular}

Based on Table 1, it can be seen that the two groups were given a pre-test to find out the initial state of the difference between the experimental group (E) and the control group (K). After the pre-test, it was known that the two groups on the same condition, so the experimental class was treated by using an inquiry model based on local wisdom on the theme of heat and its transfer (X), while the control class only used the inquiry model treatment on the theme of heat and its transfer (Y).

To find out the amount of improvement in students' understanding of concepts before being given treatment and after receiving treatment using an inquiry model based on local wisdom, it was analyzed by using a normalized gain test (gain score), which is indicated by the difference in scores between the pre-test and post-test.

The average difference test used the independent sample t-test to compare students' conceptual understanding of the experimental class and the control class. The hypothesis testing is as follows:
$H_{0}: \mu_{1}=\mu_{2} \quad$ (There is no difference in conceptual understanding between the inquiry class and the local wisdom-based inquiry class)
$H_{1}: \mu_{1} \neq \mu_{2} \quad$ (there are differences in conceptual understanding between the inquiry class and the local wisdom-based inquiry class)

Qualitative data analysis in this study used the Miles \& Huberman model. Qualitative data analysis took place during the data collection process and after completing data collection within a certain period. For data collection technique, this study used data collection, data reduction, data display and conclusion drawing/verification.

\section{RESULTS AND DISCUSSION}

This study found that in the inquiry class, the pre-test score which was initially 52.33, increased in the post-test to 66.00 with $\mathrm{N}$-gain value of 0.28 in the low category. In the inquiry class based on local wisdom, it was obtained a 
pre-test value of 51.48 and in the post-test, it increased to 77.41 with $\mathrm{N}$-gain of 0.56 as belonged to the moderate category. To find out more about the increase in the value of understanding the concept of an inquiry class and an inquiry class based on local wisdom, it can be reviewed in Figure 1.

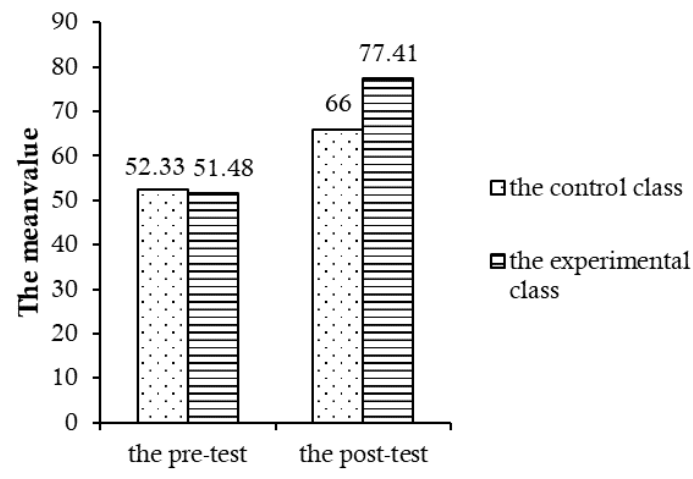

Figure 1. Improved Concept Understanding

The result of the mean value of the pretest on understanding of the concept in the inquiry model based on local wisdom was 51.48 with 7 out of 27 students completing the test. Students' understanding of the concept at the pre-test was still low because students had never received questions related to local wisdom in term of the theme of heat and its transfer that were related to the roof tiles manufacturing process occurred in the student's local environment, so that most students do not be able to answer the questions. Learning process in the class is still monotonous and passive. This can be seen from student activities during the learning process, students only listen to the teacher, students are passive when the teacher gives questions, students tend to be passive when discussing, and there are students who take notes if only instructed by the teacher. Lack of learning activities has an impact on low student learning outcomes. Yoanita \& Akhlis (2015) state that the low achievement of student in learning outcomes is due to the lack of students in understanding a concept of the material being studied. Therefore, it is important for a teacher to carry out learning by actively involvingstudents so that students can understand more a concept of material conveyed by the teacher.
After learning with the inquiry model based on local wisdom, where students were invited to make direct observations to the place where roof tiles were made, the results of the conceptual understanding score showed that the mean value of concept understanding was 51.48, increasing to 77.41. The number of students who completed the KKM was 22 out of 27 students and reached $81.48 \%$ classical completeness. There was an increase in the post-test results where questions related to local wisdom could be answered correctly by students. This is supported by the results of students' post-tests and the results of interviews with students where students better understand the material by observing directly to the place where the roof tiles are made. This is in line with the research by Ayu et al. (2017) which states that learning carried out by linking material with learning models containing local wisdom can improve student learning outcomes.

Furthermore, the percentage results of each indicator of concept understanding are calculated as in Figure 2.

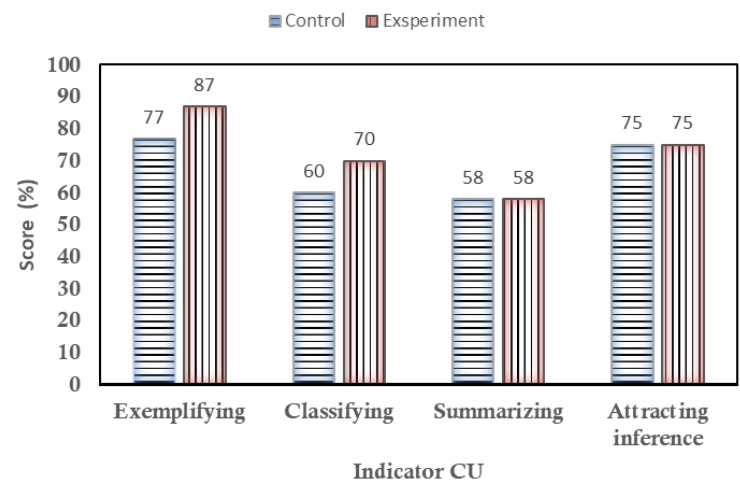

Figure 2. Percentage of Concept Understanding for each indicator

Based on Figure 2, it can be seen that the percentage results of each indicator of understanding the concept of the experimental class are higher than the control class. The percentage of each indicator class of inquiry based on local characteristics is as follows; the result of exemplifying indicator is $87.03 \%$, the classifying indicator is $70.37 \%$, the summarizing indicator is $76.54 \%$ and attracting inferences indicator is 83.33 . \%. The overall percentage 
reaches 79.32 which are in the good category. The results of the post-test show that the highest percentage of indicators is in the indicator of giving example, this is because students are invited to explore their own knowledge by making observations to the roof tiles manufacturing so that students understand the material easily and are able to provide examples of heat and its transfer. While the lowest indicator is the indicator of classification. This is because in the indicator of classification, there are several questions that belong to the difficult category. From the results of the interviews, some students were able to provide the right reasons for their answers, but there were still some that were not quite right, and were unable to classify other examples related to local wisdom.

Based on the results of the mean difference test for students' conceptual understanding, it is known that the sig. (2-tailed) value generated is $0.001<0.05$, so $\mathrm{H}_{0}$ is rejected, which means that there is a difference in understanding the concept of the inquiry class and the local wisdom-based inquiry class. The mean score for the inquiry class was 66 and the inquiry class based on local wisdom was 77.41. The mean value of local wisdom-based inquiry class is higher than the mean value of inquiry class, so it can be said that there are differences in understanding the concept of the inquiry class and the local wisdom-based inquiry class.

Learning by applying an inquiry model based on local wisdom is related to Piaget's theory of cognitive development, this stage can be seen from student activities carried out in accordance with the stages of the learning model which emphasizes students to take an active role in learning by finding and constructing their own knowledge. This is supported by the results of student observations where students actively ask the roof tile maker so as to encourage students to find new concepts and ideas and dare to express their opinions in front of the class. According to Ausubel's learning theory, the inquiry model based on local wisdom helps students to find and form concepts from the observed results so that the learning carried out by students becomes more meaningful where the new material obtained does not disappear immediately after being obtained but is understood and easier to remember. In line with the finding of Rukmana \& Alimah (2019), that the learning experiences obtained by students at each stage of the LKPD (Student Worksheets) with a learning model that involves real life events will make it easier for students to find information and make it easier for students to remember and interpret it.

The way of learning discovery intended by this study is that students conduct experiments and observations to find the science concept being studied. Students in groups carry out experimental and observation activities according to the instructions contained in the LKPD. The questions contained in the LKPD require students to find concepts from the material being studied. This is supported by students' statements from interviews that students like to work with their groups because they train students to help each other so that they are diligent and enthusiastic in working on LKPD. Therefore, students easily understand the concept of heat and its transfer from the roof tiles manufacturing process. Learning with a sociocultural inquiry model orientates learning activities to find concepts from the surrounding environment so that students not only learn material through books or teacher explanations in class but students make direct observations so they can understand the concept of science well (Nugraha et al., 2019).

According to Febriani et al. (2020), local wisdom learning strategies that utilize the environment as a necessity are very important to be maintained, developed, and preserved as learning targets, learning resources and application. In accordance with Bruner's theory, the learning model of inquiry model based on local wisdom can be seen from learning to interact with the environment. This model makes the environment as a learning resource. The use of the learning environment makes students free to learn through direct observation, discussing with the group then recording the observations and explaining them in front of the 
class. Because doing abstract science learning activities will make it difficult for students to understand the concepts conveyed (Barak \& Dori, 2011). Based on interviews with students, it shows that students are enthusiastic and attractive in learning by directly observing the concept of heat and its transfer which is associated in the process of making roof tiles.

Qualitatively, it can be explained that the profile of the conceptual understanding of class 5 students based on the results of the interview. The following is a description of concept understanding in the experimental class:

1. Subject S-24 (students with high category concept understanding test scores)

S-24 is a student whose conceptual understanding test score is in the high category. The interview was conducted as confirmation of the post-test results. S-24 students can solve all the questions given well. Before learning the inquiry model based on local wisdom, there were several questions whose answers were not quite right. This happened because the questions were deemed difficult and students had never received questions related to local wisdom, namely the learning material of heat and its transfer in the roof tile making process.

The following is an excerpt from an interview with a student who scored a high category understanding of the concept:

$\mathrm{P}$ : "Do you understand this term?"

S : "Yes Ma'am..."

$P$ : "Have you ever found a question like this?"

S : "Not yet mom, just now"

$\mathrm{P}$ : "How can you answer this question?"

S : "At first, I couldn't, ma'am! but after visiting the roof tile factory and it was explained by teacher, I understood"

In the indicator of giving example, students in the high category were able to find specific examples or a clearer understanding of a concept through observation to the roof tile manufacturing company. In the indicator of summarizing, students are also able to restate the results in general in the form of simple sentences. In addition, in the indicator of classifying, students are able to categorize, group or compare based on the concept of a material. Students' understanding of classifying is trained by giving concrete examples in the roof tilemaking place based on the type of heat transfer. While the indicator of attracting inference, high category students are able to conclude the results of the observations after direct observation to the place where the roof tiles are made.

2. Subject S-08 (students with moderate category concept understanding test scores).

$\mathrm{S}-08$ is a student whose conceptual understanding test score is in the medium category. Students with moderate conceptual understanding scores can solve all the questions given, but there are answers that are still not quite right. In the indicator of giving example, students in the medium category were able to give examples of heat and its transfer appropriately. In the indicator of classifying, students were able to provide the right reasons for the answer, but there were still some that were not quite right, and were not able to classify other examples related to local wisdom.

The following is an excerpt from an interview with a student with the moderate category concept understanding test score:

$\mathrm{P}$ : "Look at question number 5 , do you understand that?"

S : "Yes, Ma'am..."

$\mathrm{P}$ : "So, please try to mention heat and its transfer?"

S : "Conduction, convection and radiation, ma'am"

$\mathrm{P}$ : "Now, what is conduction?"

S : "Heat transfer without the transfer of particulate matter"

$\mathrm{P}$ : "Please, try to give an example?"

$\mathrm{S}$ : "The spoon we are holding is burned. Later, our hands will also feel hot, ma'am"

P: "Now, tell me an example of conduction that occurs in the process of making roof tiles."

S : "Hemmmmm ... forgot ma'am."

In the indicator of summarizing, students are able to restate the results of observations that have been done correctly, but there are still some who are still confused in summarizing the results of the observations. In the indicator of attracting 
inference, students are able to determine theright conclusions according to the questions given.

3. Subject S-02 (students with low category concept understanding test scores)

$\mathrm{S}-02$ is a student whose concept understanding test score is in the low category. Students with a score understanding of the concept below the average can solve all the number of questions, but many of their answers are not correct, because most of the questions are found difficult. Thus, students cannot answer the question correctly but are forced to fill it with hesitant answers. In the indicators of exemplifying and classifying, students are not able to name examples or classify heat transfer that occurs in the process of making roof tiles. This happens because students do not really understand the concept of heat and its transfer, one of the factors is that students are not familiar with learning that integrates with local wisdom. Besides that students also do not really understand how the process of making roof tiles is because they rarely see the process of making roof tiles or may be their parents do not have their own roof tile making production. This can be seen from the following interview excerpt:

$\mathrm{P}$ :" Look at question number 1 , what is the biggest source of heat energy in the roof tiles' combustion process?"

S : "hemmm..., is that sun?.."

$\mathrm{P}$ : "You know, what fuel do you usually use to burn roof tiles?"

S : "I don't know, ma'am"

$P$ : "Have you never seen the process of burning roof tile?"

S : "No ma'am ... hardly, I just usually passing by the location of making"

$\mathrm{P}$ : "Don't your parents have their own tile production?"

S : "No, ma'am"

The interview above proves that the work and environment around students affects students' conceptual understanding, students whose parents do not work in roof tiles or do not have their own roof tile production, do not understand the concept of heat and its transfer which is associated with the roof tile making process. Hence, when answering questions, students tend to be confused and cannot answer correctly.

In the indicator of giving example, it gets a percentage of $87.03 \%$ and is in the very good category. In the indicator of giving example, it obtained the highest percentage. The students have been able to give specific examples or a clearer picture of a concept of heat transfer through observation to the place where roof tiles are made. After learning about heat and its transfer, students were able to answer the test correctly, namely the questions about describing the form of fuel sources in roof tiles' combustion. This is in line with research by Kurniawan (2013), that direct student involvement in learning then students also actively ask questions will make it easier for students to understand the concepts given because students receive material by observing directly, so the learning material that has been delivered by the teacher will be easy for students to remember and also hard to forget.

In the indicator of classification, it shows the percentage of $70.37 \%$, meaning that in the good category. In this indicator, students are able to categorize or classify the data presented in the form of a table of types of heat transfer. Students are asked to classify the types of heat transfer, namely conduction, convection and radiation along with each example. This indicator gets the lowest percentage because some students in the low category still find it difficult to classify the types of heat transfer in the roof tile making process. Students do not understand how the roof tile making process is because some students are still busy and playing alone and they also rarely see the roof tile making process because factor of parents who do not have their own roof tile-making production.

In the indicator of summarizing, the percentage of $76.54 \%$ is found in the very good category. In this indicator, students are able to restate the results in general in the form of simple sentences, restate the concept of heat, the origin of the energy source of an object and restate the convection of heat transfer incident. After making observations at the place where the roof tiles are made, students are asked to work 
on the LKPD in groups. Thus, by making observations and completing LKPD, it will help students remember the concept of heat transfer in making roof tiles so that students can answer questions correctly.

The last indicator of concept understanding is the indicator of attracting inference. The inference aspect is observed by using the concepts that have been studied and relating them to the research results to obtain conclusions. This indicator obtained a percentage of $83.33 \%$. High category students have been able to conclude the results of observations after direct observation to the roof tile manufacturing company. This is in line with Simsek \& Kabapinar (2010) which states that in the activity of attracting inference, students are required to obtain concepts from the results of observations made and relate them to material concepts that have been studied and can be obtained through various learning sources.

Understanding of the concept which includes the aspects of exemplifying, classifying, summarizing and attracting inference through the application of learning with an inquiry model based on local wisdom has increased. This is supported by the statement of Mavuru \& Umesh (2017), that conducted research by using local wisdom with an inquiry model and found that a learning model that is integrated with local wisdom will create meaningful learning situations so that students' ability to analyze can develop and make students understand and master the materials being learned.

\section{CONCLUSION}

Inquiry model based on local wisdom can improve students' conceptual understanding on the theme of heat and its transfer. The results of the average difference test for students' conceptual understanding stated that there were differences in conceptual understanding between the inquiry class and the local wisdom-based inquiry class. The profile of students' conceptual understanding in the aspects of exemplifying, classifying, summarizing and attracting inferences is included in the good category.
Most students are able to provide specific examples or clearer understanding of the concept of heat transfer through observation to the roof tile manufacturing company. Students are also able to classify the types of heat transfer, namely conduction, convection and radiation and their respective examples. There are still some students who have difficulty understanding the material because students are busy and playing alone or because their parents who do not have their own roof tile production. In the indicators of summarizing and attracting inferences, students are able to summarize and conclude the results of their observations after conducting direct observation at the roof tile manufacturing company. Inquiry learning based on local wisdom makes it easier for students to understand the material conveyed through direct observation to the place where roof tiles are made..

\section{REFERENCES}

Alimah, S. (2019). Kearifan Lokal dalam Inovasi Pembelajaran Biologi : Strategi Membangun Anak Indonesia yang Literasi dan Berkarakter untuk Konservasi Alam. Jurnal Pendidikan Hayati. 5 (1) :1-9.

Anam,A.C, Wiyanto \& Alimah,S. (2019). The Analysis of Students' Conceptual Understanding and Motivation in Guided Inquiry Science Learning Model Assisted by Android Virtual Laboratory. Journal of Primary Education. 8(2): 163-172.

Atmojo, S.E. (2012). Profil Keterampilan Proses Sains dan Apresiasi Siswa terhadap Profesi Pengrajin Tempe dalam Pembelajaran IPA Berpendekatan Entosains. Jurnal Pendidikan IPA Indonesia. 1(2): 115-122.

Ayu, A., Wahyuni, S. \& Putra, P. (2017). Utilizing of Comic and Jember's Local Wisdom as Integrated Science Learning Materials. International Journal of Social Science and Humanity. 7 (1):47-50.

Barak, M. \& Dori,Y.J. (2011). Science Education in Primary School: Is an 
Animation Worth a Thousand Picture? Journal of Science Education and Technology. 20:608-620.

Dewi, Ni, P.S., Wibawa, I.M. \& Devi, N.L. (2017). Kemampuan Berpikir Kritis dan Keterampilan Proses dalam Pembelajaran Siklus Belajar 7E Berbasis Kearifan Lokal. Jurnal Pendidikan Indonesia. 6 (1): 125-133.

Febriani,E.M, Sudarmin \& Alimah,S. (2020). Local Wisdom Learning Approach Towards Students Learning Outcomes. Journal of Primary Education. 9 (2): 197-205.

Hariyadi, D., Ibrohim \& Rahayu. S. (2016). Pengaruh Model Pembelajaran Inkuiri Terbimbing Berbasis Lingkungan terhadap Keterampilan Proses dan Penguasaan Konsep IPA Siswa Kelas II pada Materi Ekosistem. Jurnal Pendidikan. 1 (8) : 1567-1574.

Kemendikbud. (2013). Ilmu Pengetahuan Alam SMP/Mts Kelas VII. Jakarta: Politeknik Media Kreatif

Khusniati, M. (2014). Model Pembelajaran Sains Berbasis Kearifan Lokal dalam Menumbuhkan Karakter Konservasi. Indonesia. Journal of Conservation, 3(1): 6774.

Kurniawan, A.D. (2013). Metode Inkuiri Terbimbing dalam Pembuatan Media Pembelajaran Biologi untuk Meningkatkan Pemahaman Konsep dan Kreativitas Siswa SMP. Jurnal Pendidikan IPA Indonesia. 2 (1): 8-11.

Lathifah, I.N. \& Wilujeng. I. (2016). Pengembangan Perangkat Pembelajaran Integrated Science Berbasis Kearifan Lokal. Jurnal Pendidikan Matematika dan Sains. 4 (2): 120-129.

Mavuru, L \& Umesh, R. (2017). Teachers' Knowledge and Views on the Use of Learners' Socio-Cultural Background in Teaching Natural Sciences in Grade 9 Township Classes. African Journal of Research in Mathematics, Science and Technology Education. 21 (2): 176-187.
Nafisah, Z \& Ansori, M. (2019). Pemberdayaan Potensi Desa Wisata River Walk di Desa Papasan Kecamatan Bangsri Kabupaten Jepara. Jurnal Warta Pengabdian. 13(4): 157-163.

Nugraha, E.S., Hartono \& Nuswowati, M. (2019). Improving Science Process Skills Through the Socio-Cultural Inquiry Model. Journal of Primary Education. 8 (2): 192-199.

Pramadi, I.P., Suastra.I.W. \& Candiasa I.M. (2013). Pengaruh Penggunaan Komik Berorientasi Kearifan Lokal Bali terhadap Motivasi Belajar dan Pemahaman Konsep Fisika. E-journal pascasarjana Universitas Pendidikan Ganesha. 3 (1): 24-34.

Rahmani, Halim, A. \& Jalil, Z. (2016). Penerapan Model Pembelajaran Inkuiri Terbimbing untuk Meningkatkan Keterampilan Proses Sains (KPS) Siswa Sekolah Dasar. Jurnal Pencerahan, 10 (2): 74-80.

Rukmana,S dan Alimah, S. (2019). Students Worksheet Based on 7E Learning Cycle: Strategies to Improve Activities and Understanding the Concept of Excretion System in MA. Journal of Biology Education. 8 (2): 226-237.

Simsek, P \& Kabapnar, F. (2010). The Effects of Inquiry-Based Learning on Elementary Students'conceptual Understanding of Matter, Scientific Process Skills and Science Attitudes. Procedia Social and Behavioral Sciences. 2 (1): 1190-1194.

Winnie, W.M. (2014). Representational Practices in Extra-Curricular Science Inquiry Projects : A Study with Asian Primary Pupils. International Journal of Science and Mathematics Education. 1: 1-25.

Yoanita, P. \& Akhlis, I. (2015). Pengembangan E-Diagnostic Test Untuk Identifikasi Tingkat Pemahaman Konsep Siswa SMP Pada Tema Optik dan Pengelihatan. Unnes Science Education Journal.4 (1): 815 822 . 